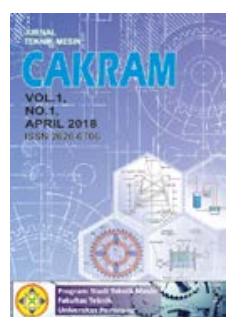

\title{
PERHITUNGAN THERMODYNAMIC PROPERTIES PADA PIPA KAPILER EKSPANSI PADA SISTEM REFRIGERASI ABSORPSI AMONIA
}

\author{
Nailul 'Atifah ${ }^{1}$, Yohan², Mochamad Kiki Triyansyah ${ }^{3}$ \\ ${ }^{1,2,3}$ Program Studi Teknik Mesin, Universitas Pamulang, Jl. Surya Kencana No.1, Tangerang Selatan, Indonesia \\ E-mail : ${ }^{1}$ dosen00410@unpam.ac.id
}

Masuk : 27 Februari 2019

Direvisi : 12 Maret 2019

Disetujui : 22 Maret 2019

\begin{abstract}
Abstrak: Penelitian mengenai perhitungan thermodynamic properties pada pipa kapiler ekspansi pada sistem refrigerasi ammonia telah dilaksanakan. Proses ekspansi isenthalpic R717 ini beroperasi pada temperatur input sebesar $30^{\circ} \mathrm{C}$ dan temperatur output sebesar- $15^{\circ} \mathrm{C}$ dengan nilai enthalpi sebesar $339,04 \mathrm{~kJ} / \mathrm{kg}$. Nilai tekanan input adalah $1166,93 \mathrm{kPa}$ dan tekanan outputnya adalah 236,20 kPa. Laju aliran massa refrigerant R717 yang dioperasikan adalah sebesar 0,0031 kg/s. Penelitian ini bertujuan untuk menghitung kebutuhan panjang pipa kapiler dengan variasi diameter 0,026 inchi, 0,031 inchi, dan 0,042 inchi serta mengetahui bagaimana perubahan temperatur, tekanan dan fraksi uap di sepanjang pipa kapiler dengan variasi diameter tersebut. Hasil perhitungan menunjukkan bahwa semakin besar diameter pipa kapilernya maka semakin panjang kebutuhan pipanya. Pipa kapiler berdiameter 0,026 inchi, 0,031 inchi, 0,042 inchi memerlukan panjang pipa kapiler masingmasing sebesar 0,249 m, 0,368 m dan 0,959 m. Penurunan temperatur dan tekanan refrigerant R717 di sepanjang pipa kapiler pada semua varisi diameter tersebut bersifat tidak linier terhadap kenaikan panjang pipa. Terjadi penurunan temperatur dan tekanan yang curam di bagian akhir alirannya. Kenaikan fraksi uap refrigerant R717 di sepanjang pipa kapiler pada semua varisi diameter tersebut bersifat tidak linier terhadap kenaikan panjang pipa. Terjadi kenaikan fraksi uap yang bersifat eksponensial di bagian akhir alirannya hingga mencapai fraksi output pda $-15^{0} \mathrm{C}$ yakni sebesar 0,158 .
\end{abstract}

Kata kunci : Pipa kapiler, diameter, R717, ekspansi isenthapic, temperatur, tekanan, fraksi uap.

Abstract: Research on the calculation of thermodynamic properties in expansion capillary pipes in the ammonia refrigeration system has been done. The isenthalpic R717 expansion process operates at input temperature of $30^{\circ} \mathrm{C}$ and output temperature of $15^{0} \mathrm{C}$ with the enthalpi value of $339.04 \mathrm{~kJ} / \mathrm{kg}$. The value of the input pressure is $1166.93 \mathrm{kPa}$ and the output pressure is 236.20 $\mathrm{kPa}$. The R717 refrigerant mass flow rate is $0.0031 \mathrm{~kg} / \mathrm{s}$. This study aims to calculate the need for capillary pipe length with the diameter variation of 0.026 inches, 0.031 inches and 0.042 inches and find out how the changes of temperature, pressure and vapor fraction along the capillary pipe with the variation in those diameter of pipes. The calculation results show that, the greater the diameter of the capillary pipe, the longer the pipe needs. Capillary pipes with a diameter of 0.026 inches, 0.031 inches, 0.042 inches require a capillary pipe length of $0.249 \mathrm{~m}, 0.368 \mathrm{~m}$ and $0.959 \mathrm{~m}$, respectively. The decrease in temperature and refrigerant pressure R717 along the capillary pipe in all diameter diameters are not linear to the increase in pipe length. Steep drop in temperature and pressure occurs at the end of the flow. The increase in refrigerant R717 vapor fraction along the capillary pipe in all diameter diameters is not linear with respect to the increase in pipe length. An exponential increase in the vapor fraction occurs at the end of the flow reaches the output fraction pda $-15^{0} \mathrm{C}$ which is equal to 0.158 .

Keywords : Capiler pipe, diameter, R717, isenthalpic expansion, temperature, pressure,fraction of vapour 


\section{PENDAHULUAN}

Dewasa ini sistem refrigerasi dengan sistem kompresi lebih banyak digunakan daripada sistem refrigerasi absorpsi karena dianggap lebih praktis. Namun di sisi lain penggunaan energi listrik untuk kerja kompresor yang digunakan relatif lebih tinggi dibandingkan dengan sistem refrigerasi absorpsi [1]. Pada sistem absorpsi peningkatan tekanan dan temperatur sebelum memasuki kondenser adalah dengan menggunakan sistem pemanasan, pertukaran panas yang bisa memanfaatkan panas matahari. Dengan demikian diharapkan dapat mengurangi beban konsumsi energi listrik. Penelitian kali ini berfokus pada bagian ekspansi isenthalpic di sepanjang pipa kapiler yang menghubungkan antara output kondenser dan input evaporator. Sistem yang dikaji berkapasitas 1 PK dengan temperatur masuk $30^{\circ} \mathrm{C}$ dan temperatur keluaran $-15^{\circ} \mathrm{C}$. Laju aliran massa refrigerant R717 yang dioperasikan adalah sebesar $0,0031 \mathrm{~kg} / \mathrm{s}$. Penelitian ini bertujuan untuk menghitung perubahan temperatur, tekanan, dan fraksi uap di sepanjang pipa kapiler dengan variasi diameter 0,026 inchi, 0,031 inchi, dan 0,042 inchi. Penelitian ini juga bertujuan untuk menghitung kebutuhan panjang pipa kapiler dengan variasi diameter tersebut.

\section{METODOLOGI}

Konsep fundamental dan persamaan-persamaan yang digunakan dalam perhitungan pada penelitian ini dijabarkan dari persamaan (1) sampai dengan persamaan (9). Perhitungan kecepatan aliran refrigerant dapat ditentukan sebagai berikut [2]:

$u=\frac{\dot{m} \cdot v}{A}$

Dengan:

u $\quad$ : Kecepatan aliran refrigerant di sepanjang pipa kapiler (m/s)

$\dot{m} \quad$ : Laju aliran massa refrigerant $(\mathrm{kg} / \mathrm{s})$

$\mathrm{V} \quad$ : volume spesifik refrigeran $\left(\mathrm{m}^{3} / \mathrm{kg}\right)$

A : luas penampang aliran refrigerant $\left(\mathrm{m}^{2}\right)$

Nilai bilangan Reynolds diperoleh dengan persamaan berikut [2]:

$$
\operatorname{Re}=\frac{u \cdot D}{v \cdot \mu}
$$

Dengan:

$\begin{array}{ll}\text { Re } & \text { : Bilangan Reynolds } \\ \text { D } & : \text { Diameter pipa kapiler }(\mathrm{m}) \\ \mathrm{v} & : \text { volume jenis refrigerant }\left(\mathrm{m}^{3} / \mathrm{kg}\right) \\ \mu & : \text { viskositas refrigerant }\left(\mathrm{N} . \mathrm{s} / \mathrm{m}^{2}\right)\end{array}$

Faktor friksi f dapat dihitung dengan persamaan berikut [2]:

$$
f=\frac{1}{3 \cdot \operatorname{Re}^{0,25}}
$$


Dengan:

f $\quad$ : faktor friksi

Nilai fraksi uap dapat ditentukan dengan persamaan berikut[3]:

$$
x=\frac{h-h l}{h g-h l}
$$

\section{Dengan:}

x : fraksi uap

h $\quad$ : Enthalpi pada kondisi yang dimaksud $(\mathrm{kJ} / \mathrm{kg})$

hl : Enthalpi pada kondisi cair jenuh $(\mathrm{kJ} / \mathrm{kg})$

hg : : Enthalpi pada kondisi uap jenuh $(\mathrm{kJ} / \mathrm{kg})$

Karena proses ekspansi berjalan secara isenthalpic maka $h_{i+1}=h_{i}[4]$

Nilai volume spesifik campuran dan viskositas campuran liquid dan gas dapat ditentukan dengan persamaan berikut [5]:

$v=(1-x) . v l+x . v g$

Dengan:

v : volume spesifik campuran $\left(\mathrm{m}^{3} / \mathrm{kg}\right)$

vl : volume spesifik cair jenuh $\left(\mathrm{m}^{3} / \mathrm{kg}\right)$

vg : volume spesifik gas jenuh $\left(\mathrm{m}^{3} / \mathrm{kg}\right)$

$\mu=(1-x) \cdot \mu l+x \cdot \mu g$

Dengan:

$\mu \quad$ : viskositas campuran (N.s/m²)

$\mu l \quad$ : viskositas cair jenuh (N.s $/ \mathrm{m}^{2}$ )

$\mu g \quad$ : viskositas gas jenuh (N.s/m²)

Faktor friksi rata-rata pada state i+1 adalah [6] :

$$
f_{\text {avgi }}=\frac{f_{i}+f_{i+1}}{2}
$$

Kecepatan rata-rata pada state $\mathrm{i}+1$ adalah :

$$
u_{a v g i}=\frac{u_{i}+u_{i+1}}{2}
$$


Volume spesifik rata-rata pada state $\mathrm{i}+1$ adalah :

$v_{a v g i}=\frac{v_{i}+v_{i+1}}{2}$

Berdasarkan neraca kekekalan energi dan hukum bernouli di sepanjang pipa kapiler, maka nilai $\Delta L$ dapat ditentukan sebagai berikut [7], [8]:

$$
\Delta L_{i}=\frac{\left\{\frac{\dot{m}}{A}\left(u_{i+1}-u_{i}\right)-\left(P_{i+1}-P_{i}\right)\right\} \cdot D \cdot v_{a v g}}{f_{a v g} \cdot u_{a v g}^{2}}
$$

Gambar 1. Menunjukkan diagram alir perhitungan dan analisis pipa kapiler pada penelitian ini:

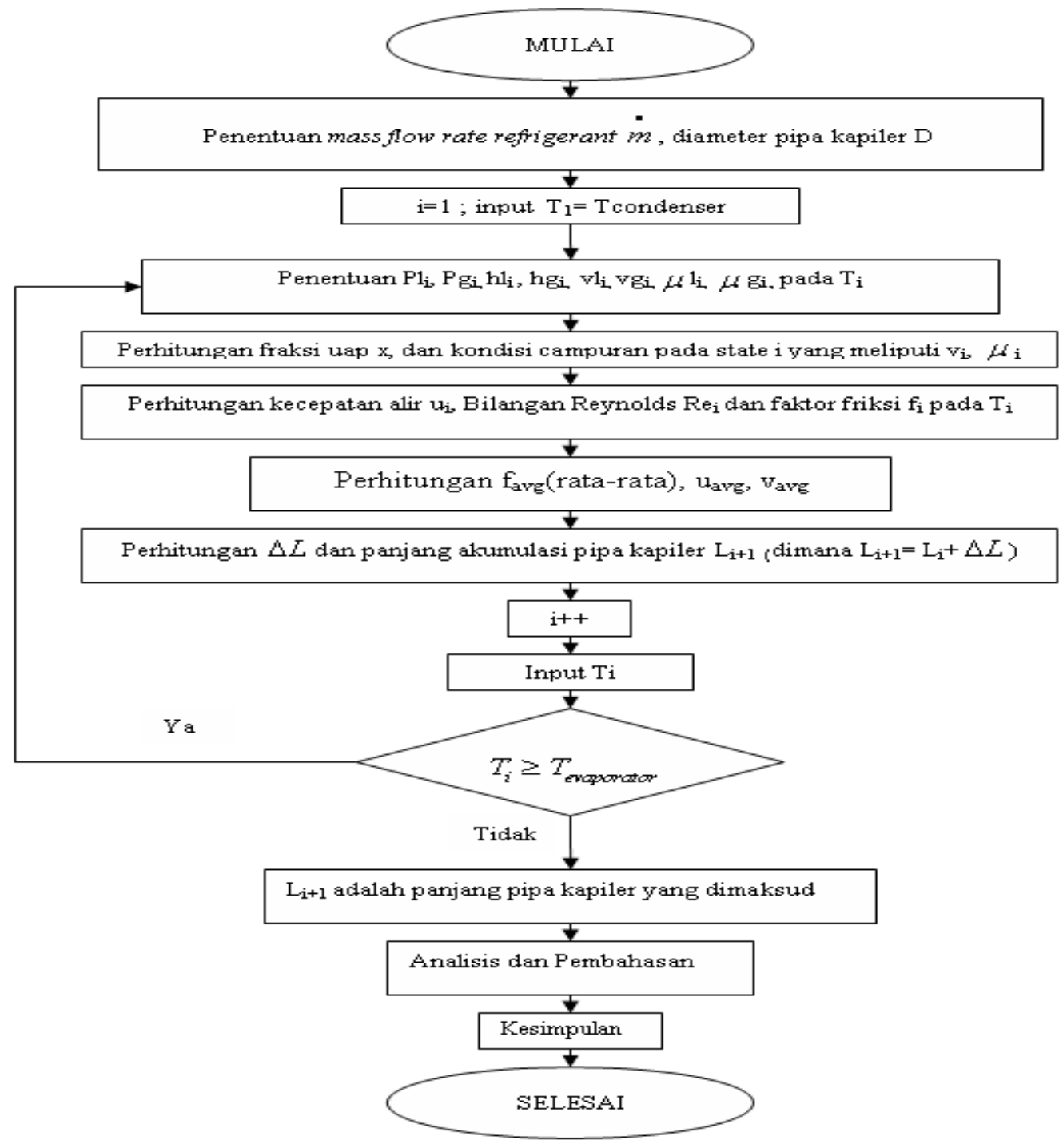

Gambar 1. Diagram Alir Perhitungan dan Analisi 
Tahap perhitungan berikutnya untuk state iterasi selanjutnya yakni i+1 juga mengulangi step penjabaran perhitungan dari persamaan (1) sampai persamaan (9) di atas [8]. Dengan demikian diperoleh bagaimana perubahan nilai fraksi, temperatur dan tekanan di sebanjang pipa kapiler. Pada proses ekspansi, refrigerant yang mengalir mengalami ekspansi isenthalpic. Pada proses ini terjadi penurunan tekanan dan temperatur refrigerant di sepanjang pipa kapilernya. Akan tetapi fraksi uapnya mengalami kenaikan mulai dari nol (fase cair jenuh) ketika keluar dari condenser memasuki sistem ekspansi hingga keluar dari pipa kapiler dengan fraksi tertentu [9].

Penelitian ini mengambil kasus sistem refrigerasi dengan refrigerant R717 (amonia). Suhu input pada awal yang merupakan proses ekspansi adalah $30^{\circ} \mathrm{C}$. Pada kondisi ini, fase refrigerant adalah cair jenuh. Dengan demikian nilai enthalpi masuk $\mathrm{h}_{1}$ adalah sama dengan nilai enthalpi pada kondisi cair jenuhnya [10]. Gambar 2. menunjukkan hasil perhitungan dengan software Coolpack diperoleh nilai-nilai pada state $\mathrm{i}=1$ sebagai berikut:

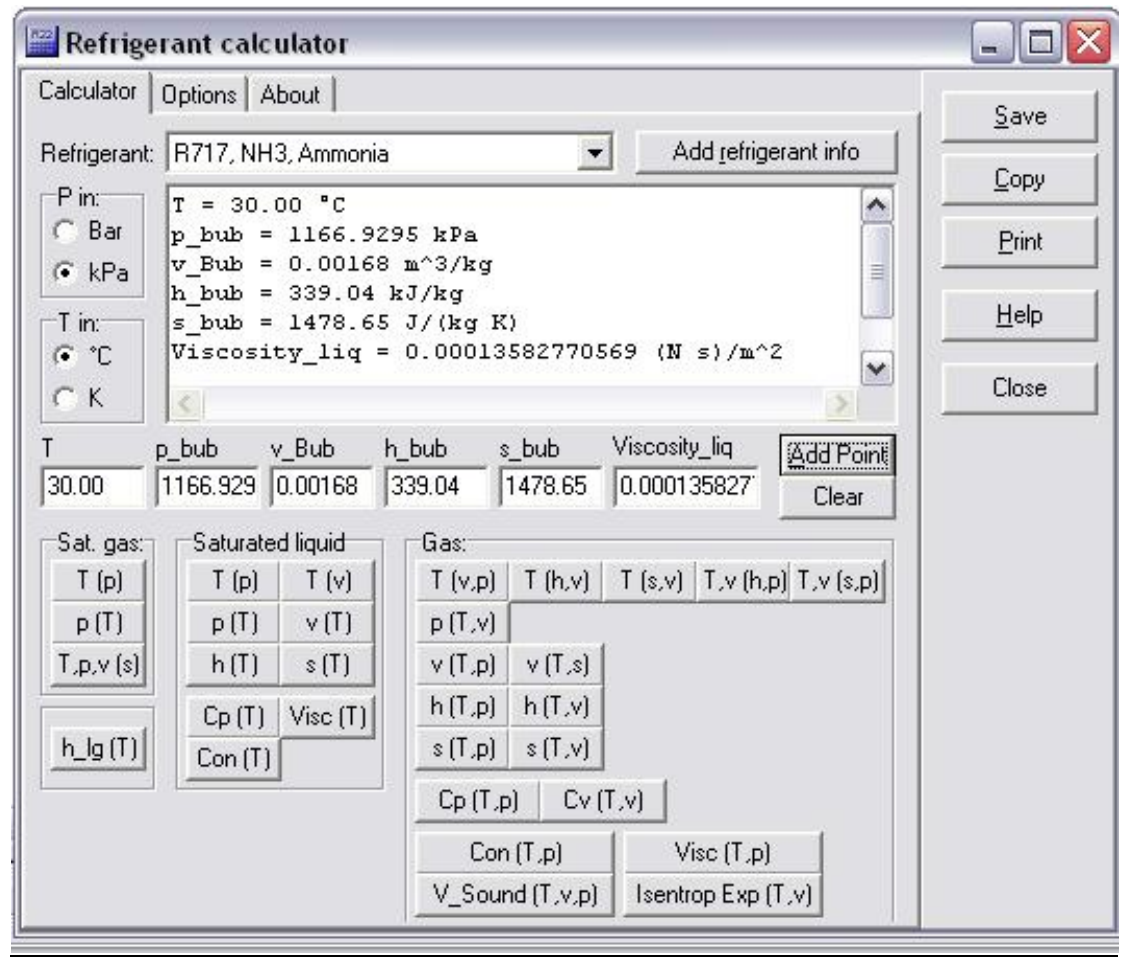

Gambar 2. Hasil Simulasi Perhitungan dengan software Coolpack state $\mathrm{i}=1$ dengan $\mathrm{T}_{1}=30^{\circ} \mathrm{C}$.

Gambar 3. menyajikan grafik yang menunjukkan bagaimana perubahan temperatur refrigerant di sepanjang pipa kapiler berdasarkan persamaan (1) sampai dengan (9) dan kaidah diagram alir yang disajikan pada Gambar (3) dengan variasi diameter 0,026 inchi, 0,031 inchi, dan 0,042 inchi. Dari Gambar 3. tersebut dapat dilihat bahwa semakin panjang pipa kapiler, semakin terjadi penurunan temperatur. Penurunan temperatur tidak terjadi secara linier. Hal ini dapat dilihat dari penurunan yang curam di akhir- akhir alirannya. Dari grafik pada Gambar 3. tersebut juga dapat diilihat bahwa untuk mencapai suhu evaporasi yang sama yakni $-15^{0} \mathrm{C}$, semakin besar diameter pipa kapiler yang digunakan, maka kebutuhan panjang pipanya juga semakin besar. Proses ekspansi dengan pipa kapiler berdiameter 0,026 inchi memerlukan panjang pipa kapiler sebesar 0,249 m. Proses ekspansi dengan pipa kapiler berdiameter 0,031 inchi memerlukan panjang pipa kapiler sebesar 0,368 m. Sedangkan proses ekspansi dengan pipa kapiler berdiameter 0,042 inchi memerlukan panjang pipa kapiler sebesar 0,959 m. 


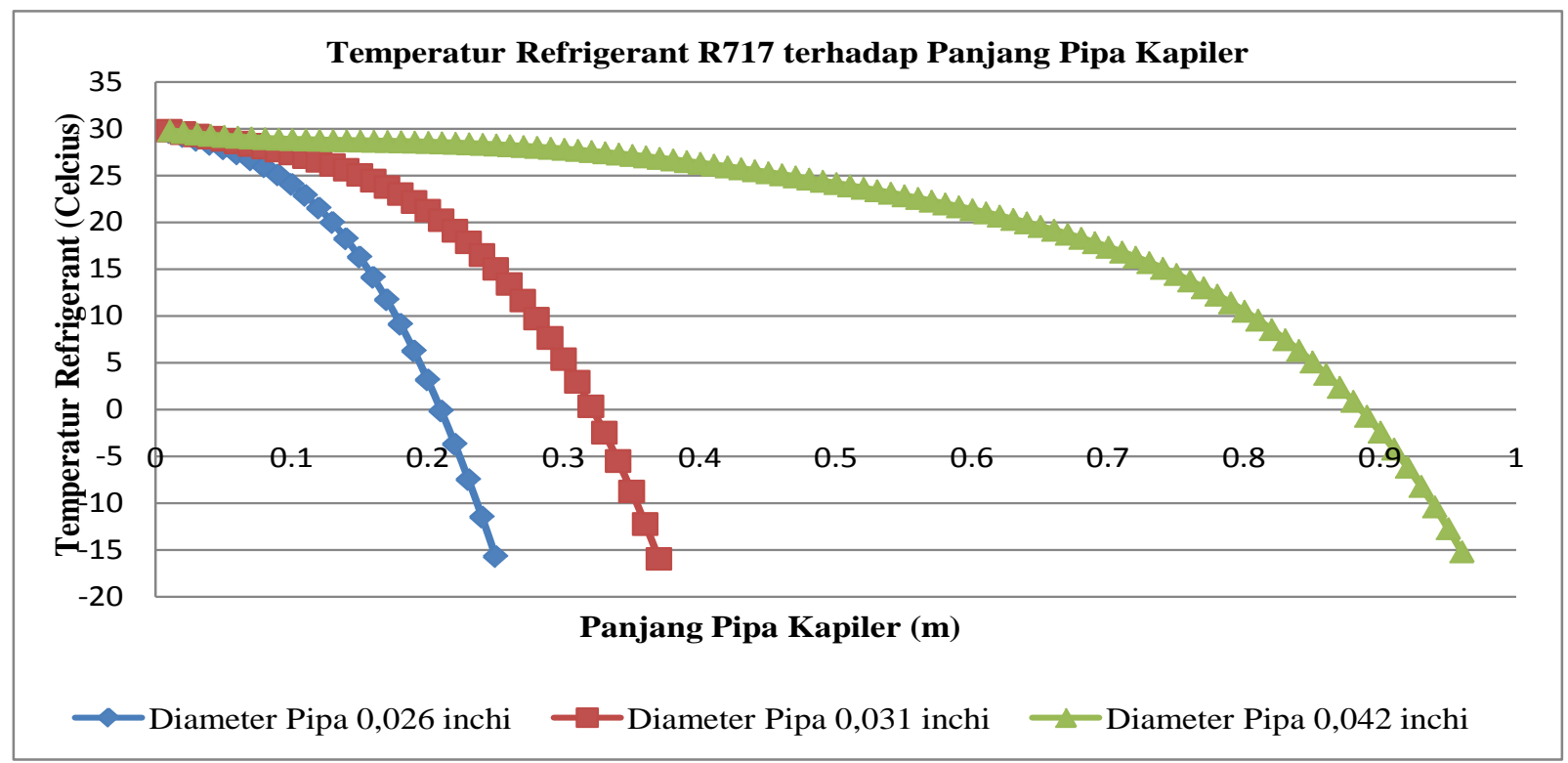

Gambar 3. Temperatur Refrigerant R717 terhadap Panjang Pipa Kapiler

Gambar 4. menyajikan grafik yang menunjukkan bagaimana perubahan fraksi uap refrigerant R 717 di sepanjang pipa kapiler berdasarkan persamaan (1) sampai dengan (9) dan kaidah diagram alir yang disajikan pada Gambar (3) dengan variasi diameter 0,026 inchi, 0,031 inchi, dan 0,042 inchi.

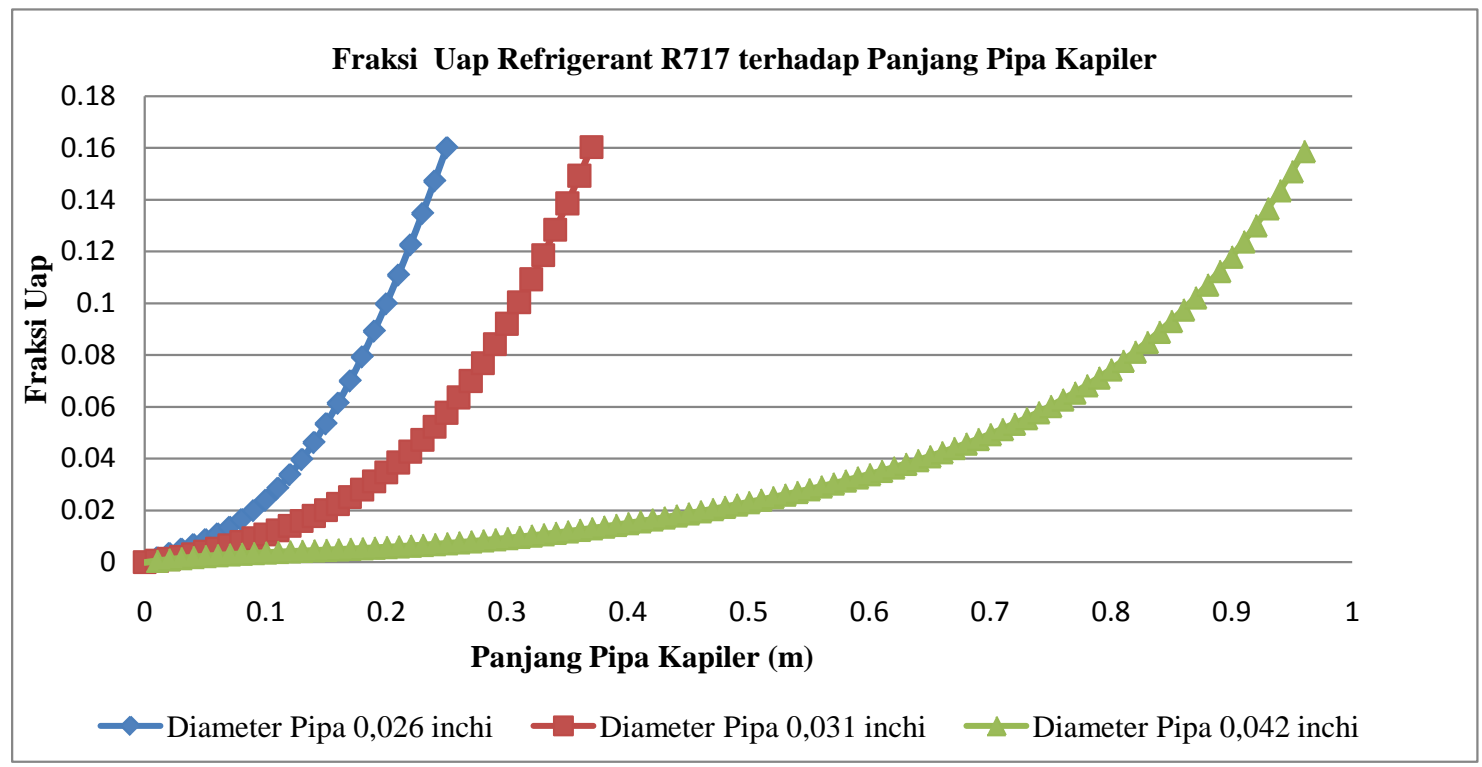

Gambar 4. Fraksi Uap Refrigerant R717 terhadap Panjang Pipa Kapiler

Dari grafik pada Gambar 4. tersebut dapat dilihat bahwa semakin panjang pipa kapiler, semakin terjadi kenaikan fraksi uap. Fraksi uap keluaran pada output ekspansi dari pipa kapiler dengan temperatur $-15^{0} \mathrm{C}$ adalah sebesar 0,158. Kenaikan fraksi uap ini tidak terjadi secara linier terhadap panjang pia kapiler. Hal ini dapat dilihat dari kenaikan nilai fraksi uap yang terjadi secara eksponensial di akhir- akhir alirannya. Dari grafik pada Gambar 4. tersebut juga dapat diilihat bahwa untuk mencapai fraksi uap yang sama yakni 0,158, semakin besar diameter pipa 
kapiler yang digunakan, maka kebutuhan panjang pipanya juga semakin besar. Dengan nilai yang teleh dijabarkan sebelumnya.

Gambar 5. menyajikan grafik yang menunjukkan bagaimana perubahan tekanan refrigerant $\mathrm{R} 717$ di sepanjang pipa kapiler berdasarkan persamaan (1) sampai dengan (9) dan kaidah diagram alir yang disajikan pada Gambar (3) dengan variasi diameter 0,026 inchi, 0,031 inchi, dan 0,042 inchi.

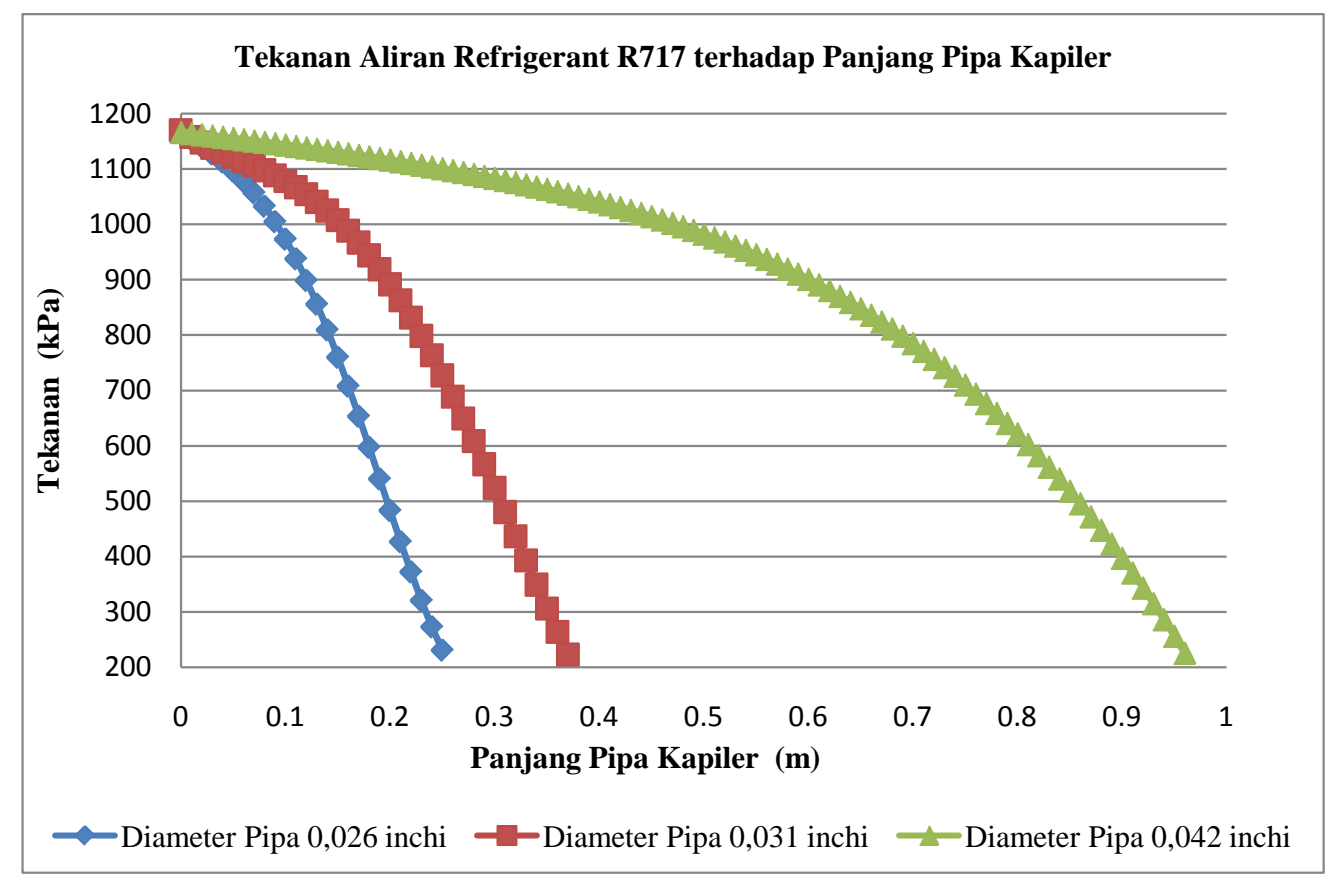

Gambar 5. Tekanan Refrigerant R717 terhadap Panjang Pipa Kapiler

Dari grafik pada Gambar 5. tersebut dapat dilihat bahwa semakin panjang pipa kapiler, semakin terjadi penurunan tekanan refrigerant. Tekanan input ekspansi pada pipa kapiler dengan temperatur awal $30^{0} \mathrm{C}$ seperti yang ditunjukkan pada Gambar 2. adalah sebesar 1166,93 kPa. Sedangkan tekanan ouput ekspansi pada pipa kapiler dengan temperatur akhir adalah $-15^{\circ} \mathrm{C}$ adalah sebesar 236,20 kPa. Penurunan tekanan refrigerant R717 ini tidak terjadi secara linier terhadap panjang pia kapiler. Hal ini dapat dilihat dari penurunan tekanan refrigerant yang curam di akhir- akhir alirannya. Dari grafik pada Gambar 5. tersebut juga dapat diilihat bahwa untuk mencapai tekanan output yang sama yakni 236,20 kPa, semakin besar diameter pipa kapiler yang digunakan, maka kebutuhan panjang pipanya juga semakin besar.

Diagram T-s yang menunjukkan perubahan thermodynamic properties dari input proses sampai pada output proses ekspansi dapat dilihat dari Gambar 6 berikut: 


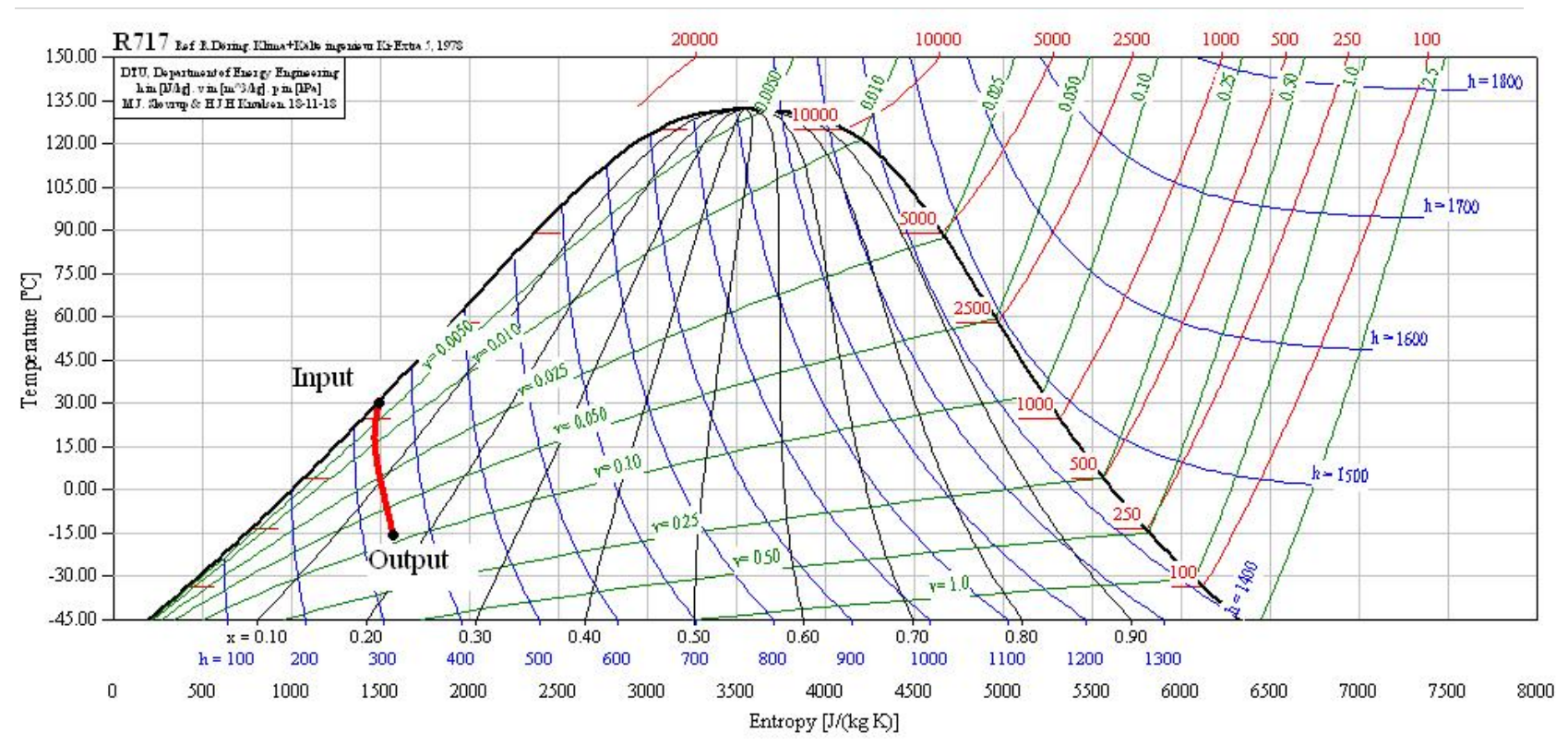

Gambar 6. Diagram T-s untuk Proses Ekspansi Isenthalpic dari $30^{\circ} \mathrm{C}$ menjadi $-15^{0} \mathrm{C}$

\section{KESIMPULAN}

Dari hasil perhitungan dan analisis pada penelitian ini dapat disumpulkan hal-hal sebagai berikut:

1. Proses ekspansi isenthalpic R717 yang beroperasi pada temperatur input sebesar $30^{\circ} \mathrm{C}$ dan temperatur output sebesar- $15^{\circ} \mathrm{C}$ memiliki nilai enthalpi konstan sebesar 339,04 kJ/kg. Sedangkan nilai tekanan inputnya adalah 1166,93kPa dan tekanan outputnya adalah 236,20 kPa.

2. Variasi diameter pipa kapiler pada proses ekspansi isenthalpic dengan refrigerant $\mathrm{R} 717$ dari suhu $30^{\circ} \mathrm{C}$ menjadi $-15^{\circ} \mathrm{C}$ menunjukkan bahwa semakin besar diameter pipa kapilernya maka semakin panjang kebutuhan pipanya. Pipa kapiler berdiameter 0,026 inchi, 0,031 inchi, 0,042 inchi memerlukan panjang pipa kapiler masing-masing sebesar 0,249 m, 0,368 m dan 0,959 m.

3. Penurunan temperatur dan tekanan refrigerant R717 di sepanjang pipa kapiler pada semua varisi diameter tersebut bersifat tidak linier terhadap kenaikan panjang pipa. Terjadi penurunan temperatur yang curam di bagian akhir alirannya.

4. Kenaikan refrigerant R717 di sepanjang pipa kapiler pada semua varisi diameter tersebut bersifat tidak linier terhadap kenaikan panjang pipa. Terjadi kenaikan fraksi uap yang bersifat eksponensial di bagian akhir alirannya.

\section{DAFTAR PUSTAKA}

1. Threlkeld, James L, 1986, Thermal Enviromental Engineering, Second Edition, Prentice-Hall, Inc, New Jersey

2. Fox, Robert W \& McDonald, Alan T, 1989, Introduction to Fluid Mechanics. John Willey \& Sons, New York 
Nailul 'Atifah, Perhitungan Thermodynamic Properties pada Pipa Kapiler Ekspansi pada Sistem Refrigerasi Absorpsi Amonia

3. Arora, C.P., 1998, Thermodynamics, Mc Graw-Hill Publishing Company, New York

4. Howel, John R \& Buckius, O Richard, 1987, Fundamentals of Engineering Thermodynamics, Mc GrawHill Publishing Company, New York

5. Prausnitz, John M, 1986, Molecular Thermodynamics of Fluid-Phase Equilibria, Prentice-Hall, Inc, New Jersey

6. White, Frank. M, 1986, Fluid Mechanics, Mc Graw-Hill Publishing Company, New York

7. Welty, James R. et al, 1984, Fundamentals of Momentum, Heat and Mass Transfer, John Willey \& Sons, New York

8. Kreyszig, Erwin, 1993, Matematika Teknik Lanjutan, Gramedia Pustaka Utama, Jakarta

9. Stoecker, W.F, et al, 1996, Refrigeration and Air Conditioning, Mc Graw-Hill Publishing Company, New York

10. Incropera, Frank.P, 1985, Fundamentals of Heat Transfer and Mass Tansfer, Second Edition, John Willey \&Sons, New York 